https://doi.org/10.52058/2786-6025-2022-1(1)-96-106

Черновалюк Ірина Володимирівна кандидат філологічних наук, доцент кафедри мовної та загальногуманітарної підготовки іноземців, Одеський національний університет імені I.I.Мечнікова, пров. Маяковського, 7, Одеса, 65023, https://orcid.org/0000-0003-2924-4036

\title{
ОСОБЛИВОСТІ ПРОФЕСІЙНОЇ МОВНОЇ ПІДГОТОВКИ ІНОЗЕМНИХ СТУДЕНТІВ
}

Анотація. Стаття присвячена проблемі професійної мовної підготовки іноземних студентів у системі вищої освіти. Проблеми професійної спрямованості у процесі навчання та мовної підготовки іноземних студентів обумовлені новими, вищими вимогами до якості опису мовного матеріалу та вимогами до підготовки фахівців. У роботі представлено основні положення методики навчання іноземної мови як засобу професійного спілкування, методичні засади у системі іншомовного спілкування професійної спрямованості. Провідною вважається концепція, згідно з якою професійна освіта насамперед має забезпечувати розвиток особистості шляхом організації його навчально-професійної діяльності. Іноземна мова розглядається як фактор формування особистості професіонала, один із засобів соціалізації випускника закладу вищої освіти, його безперервного професійного розвитку. Визначається зміст понять професійно орієнтоване навчання, принцип професійної спрямованості, професійно-комунікативна компетенція, цілі та завдання, зміст, методи навчання іноземних студентів. Виявляється місце та роль професійного мовного навчання в системі університетської підготовки фахівців 3 урахуванням сучасних вимог та підвищення якості освіти. Робиться висновок про необхідність формування професійної компетенції, яка необхідна для професійної підготовки за обраною спеціальністю. У роботі зроблено висновок щодо ефективності використання професійно орієнтованих матеріалів у процесі іншомовної діяльності 3 метою розвитку професійної та комунікативної компетенцій студентів. Практична цінність дослідження полягає у науковому обгрунтуванні та впровадженні у практику мовної підготовки іноземних студентів лінгвометодичного спрямування.

Ключові слова: іншомовне навчання, мовна підготовка, професійно орієнтоване навчання, професійна компетенція, професійне спілкування, мова спеціальності, професійно орієнтований напрямок. 


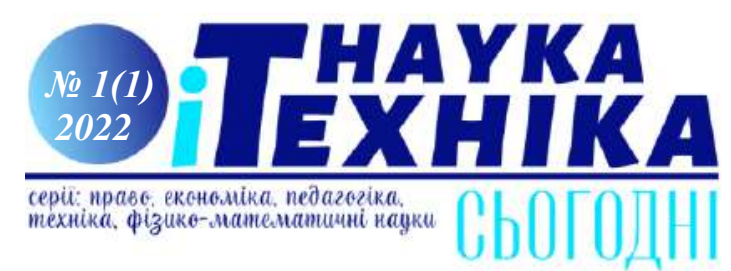

Chernovalyuk Irina Volodymyrivna Candidate of Philological Sciences, Associate Professor of the Department of Language and General Humanitarian Training of Foreigners of II Mechnikov Odessa National University; lane Mayakovskogo, 7, 65023 Odessa, Ukraine, https://orcid.org/0000-0003-2924-4036

\title{
FEATURES OF PROFESSIONAL LANGUAGE TRAINING FOR FOREIGN STUDENTS
}

\begin{abstract}
The article is devoted to the problem of professional speech training of foreign students in the system of higher education. The problems of professional orientation in the process of teaching and language training of foreign students are due to new, higher requirements for the quality of the description of language material and the requirements for training specialists. The paper presents the main provisions of the methodology of teaching a foreign language as a means of professional communication, methodological foundations in the system of foreign language communication of a professional orientation. The leading concept is considered, according to which vocational education, first of all, should ensure the development of the individual through the organization of his educational and professional activities. A foreign language is considered as a factor in the formation of the personality of a professional, one of the means of socialization of a graduate of an institution of higher education, his continuous professional development. The content of the concepts of professionally oriented education, the principles of professional orientation, professionally communicative competence, goals and objectives, content, methods of teaching foreign students are determined. The place and role of professional language training in the system of university training of specialists is revealed, taking into account modern requirements and the quality of education. It is concluded that it is necessary to form and develop professional competence, which is necessary for professional training in the chosen specialty. The practical value of the study lies in the scientific substantiation and introduction into practice of the language training of foreign students of the linguo-methodological direction.

Keywords: foreign language education, language training, professionally oriented education, professional competence, professional communication, specialty language, professionally oriented direction.
\end{abstract}

Постановка проблеми. Інтеграція національної системи освіти до європейського і світового освітнього просторів зумовлює необхідність пошуку та реалізації новітніх підходів до забезпечення теоретичної, методичної, методологічної, аксіологічної підготовки майбутніх фахівців на засадах збереження національних надбань та використання кращих зразків світового досвіду. Освіта $є$ основою інтелектуального, духовного, фізичного і 
культурного розвитку особистості, її успішної соціалізації, економічного добробуту, запорукою розвитку суспільства, об'єднаного спільними цінностями і культурою, та держави. Ціннісно-методологічним чинником стає саме освіта. Метою освіти проголошено всебічний розвиток людини як особистості та найвищої цінності суспільства, iї талантів, інтелектуальних, творчих і фізичних здібностей, формування цінностей і необхідних для успішної самореалізації компетентностей, виховання відповідальних громадян, які здатні до свідомого суспільного вибору та спрямування своєї діяльності на користь іншим людям i суспільству, збагачення на цій основі інтелектуального, економічного, творчого, культурного потенціалу Українського народу, підвищення освітнього рівня громадян задля забезпечення сталого розвитку України та іiі європейського вибору, що зазначено у Законі України «Про освіту» [1]. Реалізація поставленої мети і розв'язання завдань вищої освіти відбувається у вищих навчальних закладах України через педагогічний процес, організований відповідним чином.

Сучасні тенденції у реформуванні вищої освіти висувають нові вимоги до особистості сучасного фахівця та його професійних характеристик. За експертними оцінками, найбільш успішними на ринку праці в найближчій перспективі будуть фахівці, які вміють навчатися впродовж життя, критично мислити, ставити цілі та досягати їх, працювати в команді, спілкуватися в багатокультурному середовищі та володіти сучасними вміннями. «Інтеграція та глобалізація інформаційних i культурних процесів зумовлюють потреби модернізації освітньої системи України за всіма напрямами, що вимагає розроблення концептуальних засад у кожному 3 них. Навчання іноземних студентів $\epsilon$ одним 3 таких напрямів, важливим чинником становлення української держави як рівноправного партнера у створенні світового освітнього простору» $[11$, с.136].

Сучасна теорія та методика викладання іноземних мов розвивається у напрямі активного впровадження в освітню систему нових педагогічних рішень, методичних ідей та інноваційних технологій. У вирішенні проблем професійної освіти особистості дослідники визнають, що провідною $\epsilon$ концепція, згідно з якою професійна освіта насамперед має забезпечувати розвиток особистості шляхом організації його навчально-професійної діяльності. Ця концепція $\epsilon$ актуальною і для підготовки іноземних студентів в українських закладах вищої освіти (ЗВО). Проблема формування системи професійної мовної підготовки іноземних студентів під час навчання у ЗВО на різних освітніх рівнях відрізняється складністю та багатогранністю.

Аналіз основних досліджень. Аналіз науково-методичних джерел показав, що існує багато методичних напрямів і технологій навчання іноземній мові на немовних факультетах вишів. У науковій та науково-методичній літературі проблеми навчання іноземних мов у системі вищої професійної 


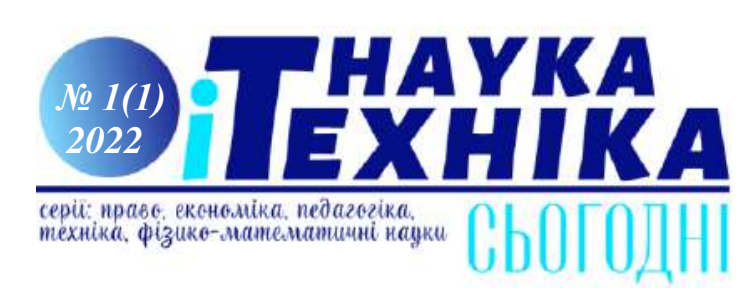

освіти досліджуються авторами з різних позицій: проблеми навчання іноземної мови у вищій школі як засобу спілкування (І.Л. Бім, Н.Н. Гез, Н.І. Жінкін, I. А. Зимова, I. В. Карпов, Б. А. Лапідус та ін); проблеми формування комунікативних умінь засобами іноземної мови (І.А. Зимова, В.Л. Кузовлєв, В.Г. Костомаров, А.А. Леонтьєв, С.І. Пассов та ін.); формування професійної спрямованості (Л.Ш. Гегечкорі, Н.I. Гез, М.А. Давидова, Б.К. Ссипович, М.К. Кабардов, Г.А. Китайгородська, Р.П. Мільруд, I.I. Халеєва та ін); проблеми мовної підготовки як складової професійної підготовки у вищій школі (Л.П.Гадзаова, Є.Н.Малюга, І.А. Рапопорт, Є.В.Воєвода, Л.П.Костикова та ін.).

Актуальною для наукових досліджень у галузі фахової підготовки $є$ проблема формування певних професійних якостей: особистої мобільності (Т.Котмакова); конкурентоспроможності (О.Романовська); професійної самосвідомості (Н.Шварп), професійна спрямованість науково-дослідної роботи студентів (С.Сфремов); проблеми професійної придатності та професійного самовиховання (О.Барно, С.Даньшева). Проте, незважаючи на велику кількість праць, питання професійно-орієнтованого навчання іноземної мови залишається досить актуальним. Питання професійно орієнтованого підходу до мовної підготовки іноземних студентів вирішені не всі, чим і пояснюється необхідність наукового та методичного обгрунтування проблеми професіоналізації у світлі сучасних вимог педагогіки вищої школи до підготовки дипломованих фахівців. Пошук шляхів удосконалення та модернізації системи навчання та мовної професійної підготовки іноземних студентів триває.

Мета дослідження. Мета цієї статті полягає у науковому обгрунтуванні основних положень методики навчання іноземної мови як засобу професійного спілкування, узагальненні методичних принципів у системі іншомовного спілкування професійної спрямованості. До основних завдань цієї статті належить визначення сутності понять професійно орієнтоване навчання, принцип професійної спрямованості, професійно-комунікативна компетенція; мети та завдань професійної мовної підготовки іноземних студентів, місця та ролі професійного мовного навчання в системі університетської підготовки фахівців з урахуванням сучасних вимог та підвищення якості освіти. Проблеми професійної спрямованості у процесі навчання мови зумовлені новими, вищими вимогами до якості опису мовного матеріалу - основи навчання. Отже, дослідження цього питання $є$ актуальним для сучасної методики викладання іноземних мов, розвитку іншомовного навчання, системи університетської мовної підготовки іноземних студентів.

Виклад основного матеріалу. Створення процесу навчання як фундаменту формування навчальної та професійної діяльності з підготовки та виховання висококваліфікованих фахівців є одним із пріоритетних завдань, що стоять перед сучасною вищою школою. Процес навчання передбачає створення 
необхідних умов підвищення загальнокультурного рівня майбутніх фахівців, культури мислення та мовлення, розширення їхнього кругозору, готовність сприяти розвитку міжкультурних зв'язків, формуванню творчого ставлення до праці. Невід'ємною частиною вищої професійної освіти іноземних студентів $\epsilon$ мовна освіта, яка має великий освітній потенціал, вирішує завдання розвитку особистості, ресурсом систематичного поповнення професійних знань, формування та розвитку комунікативних умінь та навичок. Іноземна мова в системі освітньої підготовки фахівців є засобом особистісно-професійного розвитку студентів, підвищення професійної компетентності та необхідною умовою їхньої успішної професійної діяльності в майбутньому [8, с.4].У цьому процесі вирішуються завдання навчання іноземної мови як засобу здобуття вищої освіти та спеціальності, засобу спілкування в діалозі культур та засобу гуманістичного розвитку студентів. У зв'язку з цим особливої актуальності набуває професійно орієнтований підхід до навчання іноземних студентів, який передбачає формування та розвиток здатності іншомовного спілкування у конкретних професійних, ділових, наукових сферах та ситуаціях з урахуванням особливостей професійного мислення. Важливість цього підходу обумовлена майбутньою професійною діяльністю - невід'ємною частиною життя людини, яка визначає весь життєвий уклад особистості, найближчі та перспективні цілі та завдання, формує та розвиває систему цінностей та поглядів, визначається завданнями гуманізації вищої освіти, формуванням професійної культури майбутніх фахівців сучасного рівня.

Професійно орієнтоване навчання визнається пріоритетним напрямком на сучасному етапі розвитку іншомовного навчання. Професійно орієнтований напрямок у методиці викладання іноземних мов розглядається як навчання 3 урахуванням специфіки спеціальності та майбутньої професії. Опанування мовою навчання та професійно орієнтованою мовою здійснюється одночасно 3 формуванням спеціальних навичок, заснованих на професійних та лінгвістичних знаннях, розвитком знань про культуру та традиції країни, розвитком особистісних якостей студентів [7, с.90]. Професійно орієнтоване навчання визначається як спеціально організований процес навчання іноземних студентів в умовах освітнього середовища, при організації якого враховуються освітні потреби студентів, створюються умови для їхнього професійного спрямування, що забезпечується відповідним чітким визначенням цілей, уточненням змісту і структури навчального процесу.

Професійно-комунікативна спрямована мовна підготовка є доцільною та методично виправданою системою, яка передбачає навчання студентів професійно-орієнтованого іншомовного спілкування, формування іншомовної професійно-спрямованої комунікативної компетенції - умінь і навичок здійснювати спілкування в усній і письмовій формі у межах професійної сфери i тематики, визначених програмою для кожного фаху, дотримуючись традицій i 


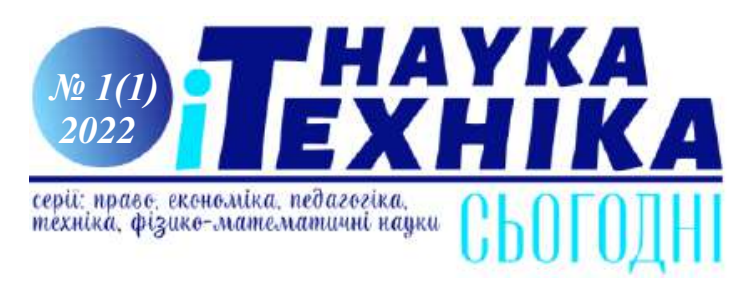

норм мови, яка вивчається, в розвитку конкретних професійних компетенцій студентів та підготовці до професійної міжкультурної комунікації [9, с.235]. Мета професійної мовної освіти полягає у підготовці фахівців, які мають комунікативні, професійні, лінгвістичні, лінгвосоціокультурні компетенції, необхідні для здійснення професійної діяльності із застосуванням іноземної мови, «формування іншомовної комунікативної компетенції є визнаною у світі загальною метою навчання усіх іноземних мов для будь-яких конкретних практичних цілей і в будь-яких видах навчальних закладів» [11]. Професійно орієнтоване навчання $\epsilon$ провідним фактором формування навчальнопрофесійної компетенції студентів. Принцип професійного комунікативного спрямування $є$ основним принципом у системі мовної підготовки іноземних студентів, який реалізується у залученні студентів в усну та письмову професійну комунікацію протягом усього курсу навчання та передбачає поетапне формування різних навичок та умінь 3 їхньою послідовною реалізацією у процесі професійної комунікації.

Важливе значення має багаторівнева система професійної мовної підготовки іноземних студентів, що дозволяє вирішувати професійні завдання відповідно до рівня володіння мовою, певного освітнього рівня та етапу навчання. Мовна підготовка іноземних студентів, магістрантів, аспірантів, стажистів повинна ураховувати їхні потреби в отриманні якісної освіти, що сприятиме подальшому особистісному зростанню, а також підвищенню престижу українських вищих навчальних закладів, української системи освіти. Мета мовної підготовки іноземних громадян полягає у забезпеченні їхніх комунікативних потреб урізних сферах спілкування: науковій (для отримання конкурентоспроможної підготовки за обраним фахом), суспільно-політичній $i$ соціально-культурній (для належної адаптації та повноцінного орієнтування в новому соціально-культурному середовищі, особистісного культурного розвитку), побутовій (для задоволення потреб повсякденного життя), а також для виховання гармонійної особистості, що здатна до міжкультурного діалогу [10; $11 ; 12]$. Професійно орієнтований напрямок у мовній підготовці іноземних студентів реалізується за допомогою спеціально організованого процесу навчання, орієнтації цілей, змісту, форм, методів та засобів навчання на майбутню спеціальність студентів, спрямованого на вирішення проблеми формування професійних навичок студентів та розвитку комунікативних умінь. Важливість забезпечення лінгводидактичної наступності різних категорій іноземців: навчання на підготовчому відділенні, бакалаври, магістри, аспіранти, стажисти $є$ пріоритетним при розробці лінгвометодичного забезпечення. Навчально-професійна діяльність іноземних студентів у процесі підготовки в українському 3ВО передбачає систематичну, свідому та поетапну діяльність студентів щодо оволодіння теоретичними основами професії, професійного розвитку та освоєння способів їх реалізації на практиці. Організаційно- 
педагогічні умови процесу навчання спрямовані на забезпечення функціонування механізмів, форм та методів професійної мовної підготовки іноземних студентів. Особливу роль має навчальне професійно-мовне комунікативне середовище. Зміст професійної мовної підготовки полягає в процесі відбору навчального матеріалу для різних спеціальностей та спеціалізацій, методів навчання, організації роботи на відповідних етапах навчання, розробку видів самостійної роботи, підготовку студентів до тестування, розробку та впровадження сучасних технологій навчання, проектування мовних та спеціальних курсів навчання та ін.

Невід'ємним компонентом системи вищої освіти $\epsilon$ його навчальнометодичне забезпечення: програми, навчальні плани, навчально-методичні комплекси, навчальні та методичні посібники, електронні підручники, словники та довідники, робочі зошити тощо. Для іноземних бакалаврів, які навчаються в ОНУ імені I.І.Мечникова за напрямом «Економіка», розроблено професійно орієнтовану програму. Робоча програма складена на основі навчальної програми 3 дисципліни «Українська мова як іноземна» відповідно до стандарту вищої освіти України з підготовки фахівців першого бакалаврського рівня спеціальності 051 «Економіка» професійної кваліфікації: Бакалавр економіки. Робоча програма розроблена на основі провідних лінгводидактичних принципів: мовна системність та функціональність, ситуативно-тематична організація та мінімізація матеріалу, комунікативна активність та креативність та ін. Програмний документ містить пояснювальну записку, необхідні інструкції 3 вивчення даної дисципліни в системі вузівської освіти, рекомендації, цілі та завдання, форми та методи навчання, основний мовний та комунікативний матеріал, конкретний зміст та обсяг знань, вимоги до мовних умінь та навичок, а також очікувані результати - компетентності, що повинен опанувати здобувач вищої освіти. У додатку представлено текстовий матеріал, актуальний та професійно орієнтований, теми для обговорення та ситуації спілкування, основний та додатковий списки навчально-методичної літератури та інтернет-ресурсів.

Метою викладання дисципліни $є$ формування практичних навичок, мовної та мовленнєвої компетенції, розвиток навичок i умінь читання, аудіювання, говоріння i письма в академічному та професійному середовищі, підвищення рівня гуманітарного освіти майбутніх фахівців у світі рішень завдань соціально-економічного розвитку. Завдання навчальної дисципліні полягає у формуванні сучасної системи спеціальних знань у галузі української мови, придбання іноземними студентами навичок та вмінь практичного використання мовних знань в умовах навчальної та професійної діяльності. Основні завдання вивчення дисципліні: розвиток необхідних мовних та мовленнєвих навичок та вмінь у всіх видах мовленнєвої діяльності для реалізації комунікативної мети навчання та задоволення 


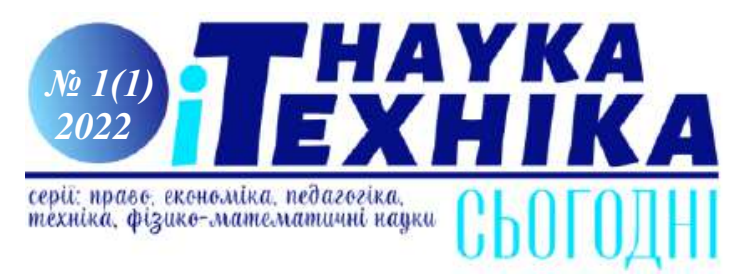

комунікативних потреб іноземних студентів; оволодіння іноземними студентами різними формами комунікації у навчально-професійній та соціально-культурній сферах спілкування в умовах мовного середовища; набуття мовних, лінгвокраїнознавчих та культурологічних знань.

Професійна спрямованість у програмі навчання іноземних бакалаврів економічної сфери реалізується в аспекті спеціально підібраного та певним чином структурованого матеріалу відповідно до тематики, що відповідає завданням професійної підготовки іноземних студентів даного напряму навчання. Цей принцип знаходить своє відображення у змістовному аспекті самої програми, співвіднесеної з цілями та завданнями підготовки майбутніх фахівців економічної сфери, у моделюванні когнітивно-комунікативного навчання, наближеного до ситуацій реального професійного спілкування. Професійний підхід до мови іноземних студентів обумовлений завданнями підготовки майбутніх фахівців економічної сфери. Головною метою навчального процесу є практичне оволодіння мовою як засобом для здобуття вищої освіти та професійних навичок, розвитку наукової та професійної компетенцій, зумовленої перспективами, пов'язаними 3 подальшим працевлаштуванням. На спеціальному текстовому матеріалі здійснюється взаємопов'язане навчання всіх видів мовної діяльності, зокрема, навчання читання та аналізу спеціальних текстів, спеціальної лексики та термінології, наукового стилю мовлення та актуальних моделей наукового стилю.

Процес навчання читання 3 розвитку професійних навичок і умінь здійснюється на спеціально підібраному матеріалі, що дозволяє навчити основним видам роботи 3 текстом, отримувати необхідну інформацію, сегментувати текст, визначати актуальний зміст. Професійно орієнтований текстовий матеріал дає можливість сформувати адекватне уявлення про функціонування даних понять у науковій мові, розширити лексичний запас учнів за допомогою спеціальних слів і термінів, познайомити 3 типовими конструкціями наукового стилю. Тексти фахового спрямування є джерелом для розширення фахового термінологічного словника, предметом читання та обговорення на заняттях, основою для використання в ситуаціях мовлення, для аудіювання, тобто для цілеспрямованої і продуктивної мовленнєвої діяльності студентів. Основними завданнями, що стоять перед студентами в процесі вивчення професійної літератури є отримання інформації, яка б доповнювала та поглиблювала навчальний матеріал, що опановується студентами в процесі вивчення профільних дисциплін навчального плану; формування необхідних навичок щодо подальшого самостійного читання літератури за фахом [14; с.152]. Особливої ваги в системі професійно орієнтованого навчання бакалаврів економічної сфери набуває лексична складова даного курсу. Вивчення професійної лексики - основи мови спеціальності $\epsilon$ одним iз найважливіших компонентів у навчальній практиці. У процесі навчання 
спеціальної лексиці та розвитку лексичної компетенції у професійному аспекті формується уявлення про системні зв'язки між лексичними одиницями, стилістичну специфіку, про їх семантичні можливості. Про сформованість лексичної компетенції свідчить знання загальнонаукової лексики, терміносистеми економічної сфери, основних понять навчального курсу, володіння лексичним мінімумом та професійною термінологією в обсязі, необхідному для опанування спеціальних дисциплін.

Висновки. Питання професійно орієнтованого навчання іншомовної діяльності на сучасному етапі вимагають нових підходів до змісту та форм навчання. Професійно орієнтоване навчання як пріоритетний напрямок сучасної іншомовної освіти потребує свого подальшого теоретичного осмислення та практичної реалізації. Процес формування професійної готовності майбутніх спеціалістів засобами іноземної мови $є$ цілісним, розвивається послідовно та логічно. У системі професійно орієнтованої мовної підготовки та навчання іноземних студентів реалізуються цілі, зміст, форми та методи педагогічної роботи. Навчання іноземних студентів 3 урахуванням професійної спрямованості сприяє оптимізації процесу навчання навчальної та наукової комунікації, удосконаленню мовної та професійної підготовки іноземних студентів, розвитку навичок професійного спілкування, підвищенню культурного та професійного рівня іноземних студентів - майбутніх спеціалістів. Педагогічний процес, спрямований на кінцевий результат навчання студента - майбутню професію, яка стане сферою застосування всіх здобутих знань, умінь, навичок, стає результативним та ефективним. Професійна мовна підготовка, таким чином, $\epsilon$ основою професійного розвитку іноземних студентів, забезпечуючи формування ключових професійно-мовних компонентів цілей, потреб, мотивів, цінностей, умінь, результатів. Перспективи дослідження проблеми бачаться в аналізі досвіду використання інноваційних технологій у процесі мовної освіти та вивчення профільних дисциплін, розробці на цій основі якісно нових навчальних завдань із навчання та професійної мовної підготовки іноземних студентів. Дослідження показало, що професійна мовна підготовка іноземних студентів в сучасному освітньому процесі потребує орієнтації у стратегії освіти на розвиток освіченої, культурної та духовної особистості як необхідної передумови розвитку суспільства, реалізації ідеї безперервної освіти.

\section{Лimepamypa:}

1. Закон України «Про освіту» [Електронний ресурс]. - 2017. - Режим доступу до pecypcy: https:// zakon.rada.gov.ua/laws/show/2145 -19.

2. Кецик-Зінченко У. В. Особливості професійно-орієнтованого навчання іноземної мови студентів немовних спеціальностей. Молодь і ринок. №9 (176). 2019. С. 101-106. 

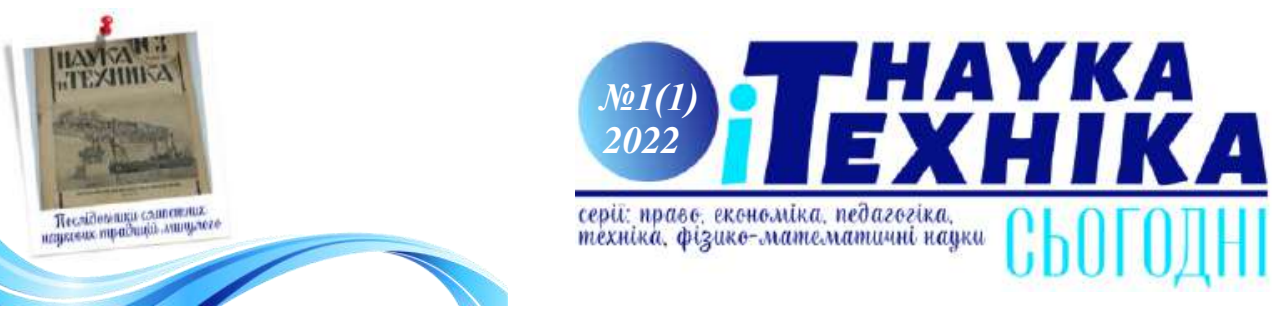

серіи: праве, екснвміка, педагогіка, техніка, фізико-манемаминиі науки

4. Koval, L.M. (2010). Formuvannia u studentiv nemovnykh vyshchykh navchalnykh zakladi anglomovnoi profesiino-orientovanoi movnoi kompetentsii [Forming English profession-oriente language competence for students of non-linguistic higher educational institutions]. Scientific Bulletin of NLTU of Ukraine. Vol.20(4), pp. 318-321. [in Ukrainian].

5. Kornjeva, Z. (2014). Komponentnyj sklad inshomovnoji profesijno orijentovanoji komunikatyvnoji kompetentnosti studentiv VTNZ [Constituents of the foreign language professional communicative competence developed at tertiary schools]. Molodj i rynok - Youth and market, 6 (113), pp.36-41 [in Ukrainian].

6. Lokshyna, O. (2019). Jevropejsjka dovidkova ramka kljuchovykh kompetentnostej dlja navchannja vprodovzh zhyttja: onovlene bachennja 2018 roku. [European reference framework of key competences for lifelong learning: an updated 2018 version]. Ukrä̈ns'kij pedagogičnyj žurnal -Ukrainian pedagogical journal, 3, pp.21-30 [in Ukrainian].

7. Nikolayeva, S.Yu. (ed). (2013). Metodyka navchannya inozemnykh mov ta kul'tur [Methodology of Teaching Foreign Languages and Cultures]. Kyiv: Lenvit Publ. [in Ukrainian].

8. Obraztsov, P.I. \& Ivanova, O.Yu. (2005). Profesionalno-orientirovannoye obuchenie inostrannomu yazyku na neyazykovykh fakultetakh vuzov [Profession-oriented teaching a foreign language at non-linguistic faculties of higher educational institutions]. Orel, 114 p. [in Russian]

9. Tarnopolsky, O.B. \& Kornieva, Z.M. (2011). Aspectniy pidhid do navchannia angliyskoi movy dlia spetsialnykh tsilei u nemovnykh VNZ [Aspect approach to learning English for special purposes in non-linguistic universities]. Herald of Kharkiv Vasyl Karazin national University. Vol.18. pp. 231-239. [in Ukrainian].

10. Ushakova, N., Trostynskaja, O., \& Kushnir, I. (2021). Stanovlenye i razvytye metodyky rechevoj podghotovky inostrannykh studentov klassycheskogho universyteta. Chastj 1 . Obuchenye studentov nejazykovym specyaljnostjam [Formation and development of methodology of language training for foreign students of a classical university. Part 1. Teaching students of non-linguistic specialties]. Vykladannia mov $u$ vyshchykh navchalnykh zakladakh osvity na suchasnomu etapi. Mizhpredmetni zviazky -Teaching Languages at Higher Institutions]. Kharkiv: V.N.Karazin Kharkiv National University, 38, pp.205-235 [in Ukrainian]. https://doi.org/10.26565/2073-4379-2021-38-14-21 [in Ukrainian]

11. Ushakova, N.I., Trostynska,O.M. and Dubichynskyj, V.V. (2011). Koncepciya movnoyi pidgotovky inozemciv $\mathrm{u}$ VNZ Ukrayiny [The conception of language training of foreigners in Ukrain ian universities]. Vykladannia mov $u$ vyshchykh navchalnykh zakladakh osvity na suchasnomu etapi. Mizhpredmetni zviazky - Teaching Languages at Higher Institutions. Kharkiv: V.N.Karazin Kharkiv National University, 19, pp.136-146 [ inUkrainian ].

12. Ushakova, N. and Trostynska, O. (2014). Vyvchennya ukrayinskoyi movy studentamyinozemcyamy: konceptualni zasady [Learning the Ukrainian language by foreign students: conceptual principles]. Teoriya $i$ praktyka vykladannya ukrayinskoyi movy yak inozemnoyi Theory and practice of teaching Ukrainian as a foreign language. Lviv: Lvivskiy nac ionalniy universitet, 9 , pp.12

13. Tsepko T.A., Androsiuk H.L. (2020). Suchasni tendenciji u vykladanni anghlijsjkoji movy zakladakh vyshhoji osvity. [Modern trends of teaching English in universities] Innovacijna pedaghoghika - Innovative Pedagogy. V.1, pp.39-43 [ inUkrainian ]. DOI: https://doi.org/10.32843/2663 6085/2019.21.3-8

14. Cherednichenko, Gh.A., Shapran, L.Ju., Kunycja, L.I. (2010). Metodyka navchannja inshomovnogho profesijno-orijentovanogho chytannja studentiv nemovnykh vyshhykh navchaljnykh zakladiv [Methods of teaching foreign language professionally oriented reading to students of nonlinguistic higher educational institutions]. Vykladannia mov $u$ vyshchykh navchalnyk $h$ zakladakh osvity na suchasnomu etapi. Mizhpredmetni zviazky - Teaching Languages at Higher Institutions. Kharkiv: V.N.Karazin Kharkiv National University, 17, pp.150-157 [inUkrainian ]. 